\title{
Equality, Justice and Identity in an Expatriate/Local Setting: Which Human Factors Enable Empowerment of Filipino Aid Workers?
}

\author{
Nigel Vaughan Smith \\ Laidlaw College, Auckland, New Zealand
}

\begin{abstract}
$T^{n}$ his study explored which of social dominance, social identity and perceptions of organisational justice were most predictive of self-reported empowerment among aid workers in the Philippines $(N=98)$. Responses to an online survey available in English and Tagalog were obtained from employees of diverse locally operating aid organisations in the Philippines. The survey included composite measures of empowerment, perceived social dominance, social identity and organisational justice. All measures except perceived social dominance performed as theorised in the Philippine context of this study. The best predictor of empowerment was the aspect of organisational justice centering on the fairness of personal interactions (interactional justice; $\beta=.331$ ). An interaction effect between interactional justice and aspects of empowerment and social (Filipino) identity was also observed $(\beta=.233$ ), implying that a secure Filipino identity may act as a buffer to consequences of injustice, all other things being equal. The overall pattern of results suggests that justice plays a more significant role than either social dominance or identity in contributing to empowerment amongst Filipino aid employees. Strikingly, interactional justice may matter more than distributive justice.
\end{abstract}

Keywords: empowerment, justice, identity, equality, Philippines, development

This article emerges from concerns that without understanding the human workplace dynamics of aid, poverty reduction may remain an elusive goal (Narayan, Pritchett, \& Kapoor, 2009). Dominance, justice and identity have been mooted as the human dynamics most critical for optimizing the effectiveness of development work (MacLachlan, Carr, \& McAuliffe, 2010). This study assessed the relative contributions that host national aid workers' perceptions of these three issues make to local capacity-building, operationally defined as the sense of empowerment among host national employees in development projects (Spreitzer, 1995).

\section{Empowerment}

There are four key cognitive assessments involved in the empowerment process (Thomas \& Velthouse, 1990); competence (self-efficacy in relation to your job); self-determination (where you locate the origin of your actions); meaning (the value you place on a work goal); and impact (the sense of making a difference in your workplace). These four components of empowerment were empirically affirmed through confirmatory factor analysis by Spreitzer (1995) on two separate American samples of employees $(N=393 ; N=128)$. This conceptualisation of empowerment is the most widely cited model of psychological empowerment in the literature (Spreitzer, 2008), with overall Cronbach's alphas ranging from .62 to 97.

The Western context in which much of the theorising of empowerment has taken place may limit its generalisability to other settings. Several studies in non-Western settings, including the Philippines, have failed to report the adequacy of the four-dimensional model of empowerment (Avolio, Zhu, Koh, \& Bhatia, 2004; Ergeneli, Sag, Ari, \& Metin, 2007; Hechanova, Alampay, \& Franco, 2006). However, factor analytic support has been found in China (Aryee \& Chen, 2006; Hui, Au, \& Fock, 2004). Due to the lack of published research exploring empowerment in non-Western contexts, the present study seeks to explore (a) whether Spreitzer and colleagues' conceptualisation of psychological empowerment is valid in the Philippines; and (b) which contributing constructs matter most in 
building local employee empowerment in aid organisations in the Philippines.

\section{Perceived Social Dominance}

The first of the antecedents considered in the present study is perceived social dominance. Perceptions of social dominance arise where hierarchical social relations occur. Those with power may both devalue target others and view themselves more favourably (Kipnis, Castell, Gergen, \& Mauch, 1976). Ironically (given the egalitarian aspirations of many in the aid sector), these outcomes are common for expatriates in aid contexts (MacLachlan, 1993). Further, expatriate-local relations in aid organisations may also be understood in these terms (MacLachlan et al., 2010); expatriates commonly form the hegemonic group, while locals, as a result of colonisation and historical racism, are often lower down the hierarchy. Consequently the present study focuses on the perceptions of, and impacts of social influence upon, local employees.

In hierarchical organisations, some people seek to establish and maintain the hierarchy through discriminative behavior (Sidanius \& Pratto, 1993). Such behaviour is likely to cause perceptions of social dominance and consequently lower levels of empowerment for those lower down the hierarchy (Essed, 2002). Expatriates may unconsciously maintain the status quo (dominating the hierarchy) rather than empowering local employees. However, employees at all levels of an organisation may hold attitudes that either strengthen (hierarchy-enhancing) or work against (hierarchy-attenuating) social dominance (Sidanius, Pratto, van Laar, \& Levin, 2004).

Consequently, where perceptions of social dominance in the organisation are high, levels of empowerment are likely to be low (Coates \& Carr, 2005; Pratto et al., 2000). It is worth noting that the present focus on perceptions of social dominance at the institutional level is at least partly a response to suggestions that research into social dominance has disproportionately focused on the individual (Sidanius \& Pratto, 2003; Turner \& Reynolds, 2003).

However, it is unclear how social dominance might operate in different cultural settings. Individual social dominance orientation was found to be relatively consistent across samples taken in Canada, Taiwan, Israel and to a lesser extent China, in correlating with sexism, ethnic prejudice and conservatism (Pratto et al., 2000). Other research supported cross-cultural validity in Sweden, Australia and Russia (Sidanius \& Pratto, 1993; Sidanius, Pratto, \& Brief, 1993) as well as cultural subgroups within the United States (Sidanius, Pratto, \& Rabinowitz, 1994). However, little research has been conducted in lowerincome, high-poverty contexts, such as the Philippines, and even less focused on perceptions of institutional social dominance.

\section{Social Identity}

Social dominance has the potential to undermine pride in identity. Social identity develops through evaluation of the characteristics of salient groups; both those one belongs to and those one does not belong to. These characteristics may include prestige (hierarchical dominance), ethnicity, or competence (Tajfel \& Turner, 2004). In turn, there are a number of consequences of strong (or weak) social identity, including increases (or decreases) in levels of empowerment (Amiot, Terry, Wirawan, \& Grice, 2010; Brown, 2000; Sheldon \& Bettencourt, 2002).

In the aid and development context, host nationals will often engage in social comparison in order to preserve the integrity of their group identity (Carr, Ehiobuche, Rugimbana \& Munro, 1996). Where the ingroup has a collectivist culture, such as in the Philippines (House, Hanges, Javidan, Dorfman, \& Gupta, 2008), these effects are likely to be stronger (Carr et al., 1996). Indeed, the present context of expatriate:local relations means ethnicity is likely to be highly salient in shaping the social identity of respondents (Toh \& Denisi, 2007; Varma, Toh, \& Budhwar, 2006).

One of the results of successful ingroup identity preservation is an increase in self-esteem felt by the members of the ingroup (Abrams \& Hogg, 1988). Empirical evidence supports a significant correlation $(r=.5 ; p<.001)$ between self-esteem and empowerment as a whole (Menon, 2001, p. 171). Thus, if host nationals' social identity is negatively valued, social identity theory (Tajfel \& Turner, 2004) would predict low levels of empowerment among Filipino aid employees.

As with empowerment and social dominance, social identity theory has been developed mainly in a Western setting (Bond \& Hewstone, 1988). In social identity theory, the out-group must be reasonably comparable (Hogg, Terry, \& White, 1995). Western expatriates may not be sufficiently similar to provoke outgroup comparison by locals (Carr et al., 1996; Coates \& Carr, 2005) in the Philippines. Additionally, any differences may be viewed as legitimate, in which case efforts to improve self-esteem (the motivation for group identity formation) may not occur (Brown, 2000). Local employees may internalise their own identity as inferior and less deserving. This possibility (which is consistent with social dominance theory) is a provocative one.

\section{Organisational Justice}

The third contributor to employee empowerment considered in this study is organisational justice. Being treated fairly (justice) is a necessary requirement for decent work, as enshrined in United Nations Millennium Development Goal 1b (United Nations, 2010, p. 8). Ironically, as MacLachlan et al. (2010) have pointed out, this ideal is far from being realised in many aid and development organisations themselves.

Justice at work was initially focused on the effect of unfair rewards on employees (Homans, 1961). This kind of justice (distributive) is about how just rewards are perceived to be in relation to those received by other salient groups of employees (Adams, 1965; Greenberg, 1987). 
Perceptions of justice were also found to be greater where people had greater control over the processes that affected them at work (procedural justice; Thibaut \& Walker, 1978). Appropriate monitoring has been found to communicate procedural justice (Niehoff \& Moorman, 1993). Criticisms of the lack of monitoring in aid work (Wenar, 2006) are therefore of potential concern.

In 1986, Bies and Moag suggested that interactional justice (the way that people are treated in their interactions within the organisation), was distinct from procedural or distributive justice (Greenberg, 1990). This distinction is important in the present context, because the way Filipino aid workers are treated within their organisations may be the most significant aspect of justice for them, because of the importance placed on interpersonal harmony within cultures high in collectivism (Beugr, 2002; Crosby, 1984).

When local employees experience low levels of distributive justice in their work environment (e.g., pay inequality), a wide range of outcomes, such as lowered job satisfaction, performance and organisational commitment may occur (Carr, Chipande, \& MacLachlan, 1998; Cohen-Charash \& Spector, 2001; Colquitt, Conlon, Wesson, Porter, \& Ng, 2001; McAuliffe, Manafa, Maseko, Bowie \& White, 2009). These suggestions have recently been substantiated in a large $(N=1,290)$ study across six countries in Africa, Oceania and Asia, where host national professionals reported both disparate levels of remuneration between locals and expatriates and a sense of relative injustice and demotivation (Carr, McWha, MacLachlan, \& Furnham, 2010).

It is worth noting that the theoretical structure of justice remains contested. In a meta-analytic attempt at clarification, Cohen-Charash and Spector (2001) affirmed the existence of distributive, procedural and interactional justice. However, other theorists (Colquitt et al., 2001; Greenberg, 1990) argued that interactional justice included two aspects, namely how information was communicated (informational justice) and how well people were treated by others (interpersonal justice). While a fourdimensional conceptualisation of justice has been found to fit the observed data better than the three-dimensional approach (Colquitt, 2001), I note that the goodness of fit of all models tested was poor to mediocre. ${ }^{1}$ I find Bies' (2005) approach informative; he believes in the two components of interactional justice, but also states that whether it is one component or two does not matter. In this study I have used a version of Niehoff and Moorman's (1993) three-dimensional justice measure similar to that adapted by McAuliffe et al. (2009).

\section{Demographic Variables}

In addition to the psychological antecedents (perceived social dominance, social identity and perceptions of organisational justice) that form the focus of this study, it is also important to acknowledge that differences in numerical group size (Doms \& van Avermaet, 1985; Latané,
1981), age (Kanter, 1979; Spreitzer, Kizilos, \& Nason, 1997) or gender (Hochwälder \& Brucefors, 2005; Spreitzer et al., 1997; Zani \& Pietrantoni, 2001) may also influence levels of empowerment.

\section{Focusing Questions}

This exploratory study, rather than proposing hypotheses to be tested, explored first, whether the constructs outlined above would be substantiated in the Philippine context; and second, which of the antecedents made the most difference to self-reported empowerment amongst the Filipino aid employees that responded to the survey.

\section{Method \\ Participants}

A total of $N=98$ Filipino aid sector employees responded to a survey invitation circulated via email by the administrators of several development associations and organisations in the Philippines (86 in English and 12 in Tagalog, the two official languages of the Philippines). Of the $N=$ 82 participants who indicated their gender, 24 (29\%) were male and $58(71 \%)$ were female. The mean age was 35.5 years, ranging from 20 to 66 years old. The mean length of employment in the aid sector was 10.9 years, ranging from 4 months to 39 years. Respondents were highly qualified, with $52 \%$ holding an undergraduate degree and a further 38\% holding a graduate degree of some kind. Analysis of respondent computer internet protocol address ownership and geographical location revealed a diverse pattern of respondents from around the Philippines. ${ }^{2}$ The sample was sufficiently varied and was adequate for exploratory research, although response rate could not be calculated.

\section{Measures}

For empowerment, perceived social dominance, social identity, justice and social desirability (provided the items factor analysed into a predicted pattern) item scores were added together and divided by the number of items to obtain mean scores per item per factor (composite scores). Factor analyses are outlined in the Results section.

Empowerment. Empowerment was measured with the multidimensional measure (Items 1-12 in Appendix) developed by Spreitzer (1995). Spreitzer (1995) reported using confirmatory factor analysis that the overall measure taps into four underlying and interrelated constructs that together represent empowerment: meaning, competence, self-determination and impact. These constructs were both scored separately and added together to constitute empowerment, depending on the focus of analysis.

Perceived social dominance. Following Coates and Carr (2005), a measure of perceived social dominance (Items 49-62 in Appendix) was adapted from Pratto, Sidanius, Stallworth, and Malle (1994). In the item 
wording, the original phrases 'some people' and 'others' were replaced with 'local workers' and 'expatriates' in order to make the intended referent groups explicit. This local adaptation follows a recommendation from Pratto et al. (2000).

Social identity. Social identity was assessed using by a 10-item measure (Items SI-33-SI-42 in Appendix) adapted from Ellemers, Kortekaas, and Ouwerkerk (1999). To maintain consistency, the same seven-item Likert scale, as in the previous questions, was used in this measure. Item wording was made more explicit in this study compared with the original measure, replacing 'the group' with 'being Filipino' or similar.

Organisational justice. Organisational justice was measured by a 20-item measure (Items 13-32 in Appendix) originally developed by Niehoff and Moorman (1993). McAuliffe et al. (2009) adapted the original measure, altering the wording of all items from individual sentences to a stem and clause format, but evaluating each item on a 5-point Likert scale. The present study uses a wording identical to McAuliffe, et al. (2009), with a reinstatement of Niehoff and Moorman's (1993) original 7-point response scale for consistency with other measures.

Demographics. A number of single questions asked respondents to provide demographic information (see Appendix A), including age, gender, years of experience working in the aid sector, job title and highest qualification. Two questions asked respondents to estimate the local: expatriate ratio of (1) salaries and (2) numbers of employees in their organisational network.

Social desirability. A measure of social desirability bias was presented together with the social identity measure. Six items (Items SD-43-SD-48 in Appendix) taken from Fischer and Fick (1993) were presented approximately alternately with those measuring social identity. Originally, the response options to these items were dichotomous (T/F). To maintain consistency with the social identity items with which these social desirability items were presented, response options ranged from 1 (Strongly disagree) to 7 (Strongly agree). Responses $>4$ were recoded $\mathrm{T}$ while responses $<4$ were recoded F. Responses of exactly 4 were recoded as missing.

\section{Procedure}

All data was collected at a single point in time via a single online survey. Significant effort went into improving the quality of measure items where rewording from the original took place, in line with recommendations from Podsakoff, MacKenzie, Lee and Podsakoff (2003). The survey was provided in both English and Tagalog, the most widespread indigenous language in the Philippines, after consultation with a cultural advisor and pilot testing. Following recommendations outlined by Brislin (1980) and Bontempo (1993), the survey was translated and back-translated by separate translators. Discrepancies between the original English version and the back-translated
English version were resolved in consultation with a third bilingual consultant. See the Appendix for the English questionnaire. The Tagalog survey is available from the author.

Protocol for factor analyses. Exploratory principal axis factoring with direct oblimin rotation was used to assess the factor structure of the multi-item measures. A Harman test (Harman, 1976) was used to assess whether a single second-order factor was also justified in each case. Where items cross-loaded evenly and significantly on more than one extracted factor, or did not load significantly on any factor, these were removed and the analysis was re-run without them (where items were deleted on either basis, this is noted on each relevant factor solution table below). Once a stable and clear factor solution had been obtained (factors required eigenvalues $>1$ ), items on each factor were summed and divided by the number of items to provide a composite and comparable variable for each factor, for each measure (Spicer, 2005). ${ }^{3}$ Where factor loading patterns were similar to those reported by the measures' authors, the present study continues to use the original factor labels, in order to maintain consistency with the relevant theory. Where the factor loadings differed from those originally reported, the label used derives from the meaning of the items loading on that factor in this study.

Protocol for regression analyses. Variables were included if they correlated significantly $(\mathrm{p}<.05)$ with the target variable for each regression (Table 5). The univariate normality of each variable was verified by checking its histogram. Bivariate homoscedascity and linearity of each variable in relation to the target dependent variable was also verified by checking a scatter-plot. As this was exploratory research, not enough was known about the relationships being explored to predetermine the order of entry into regression analyses. Therefore, simultaneous entry of variables into regression analyses was used. Once variables were all entered into the analysis, multicollinearity was checked by ensuring that the tolerance statistic was above 0.4 (Spicer, 2005). Where this was problematic, the 'offending' variable(s) was removed and the analysis was re-run. For each regression, the histogram of standardised residuals was checked to verify multivariate normality and to identify outliers. Where outliers were identified, they were removed and the analysis re-run without them. If the consequent model fit was improved, the outliers remained excluded, otherwise they were returned to the analysis (Spicer, 2005). Multivariate homoscedascity and linearity were verified by checking the scatterplot of standardised residuals vs. standardised predicted values.

\section{Results}

\section{Assessing Construct Performance: Factor Analyses}

Empowerment. The analysis resulted in four meaningful factors: meaning $(\alpha=.799)$; competence $(\alpha=.831)$; 
Table 1

Factor Solution for Empowerment Measure

\begin{tabular}{|c|c|c|c|c|c|}
\hline \multirow[b]{2}{*}{ Factor } & \multirow[b]{2}{*}{ Item } & \multicolumn{4}{|c|}{ Factor } \\
\hline & & Competence & $\begin{array}{c}\text { Self- } \\
\text { determination }\end{array}$ & Meaning & Impact \\
\hline \multirow[t]{3}{*}{ Competence } & I am self-assured about my capabilities to perform my work activities & .882 & & & \\
\hline & I am confident about my ability to do my job & 832 & & & \\
\hline & I have mastered the skills necessary for my job & .646 & & & \\
\hline \multirow[t]{3}{*}{ Self-determination } & $\begin{array}{l}\text { I have considerable opportunity for independence and freedom in } \\
\text { how I do my job }\end{array}$ & & -.923 & & \\
\hline & I can decide on my own how to go about doing my work & & -.905 & & \\
\hline & I have significant autonomy in determining how I do my job & & -.759 & & \\
\hline \multirow[t]{3}{*}{ Meaning } & My job activities are personally meaningful to me & & & .936 & \\
\hline & The work I do is meaningful to me & & & .846 & \\
\hline & The work I do is very important to me & & & .383 & \\
\hline \multirow[t]{3}{*}{ Impact } & $\begin{array}{l}\text { I have significant influence over what happens in my department or } \\
\text { workgroup }\end{array}$ & & & & -.943 \\
\hline & $\begin{array}{l}\text { I have a great deal of control over what happens in my department } \\
\text { or workgroup }\end{array}$ & & & & -.646 \\
\hline & My impact on what happens in my department or workgroup is large & & & & -.520 \\
\hline Eigenvalue & & 5.233 & 1.918 & 1.348 & 1.012 \\
\hline$\%$ Variance & & 43.610 & 15.984 & 11.237 & 8.432 \\
\hline Total Variance & & 43.610 & 59.595 & 70.832 & 79.264 \\
\hline Cronbach's Alpha & & .831 & .909 & .799 & .830 \\
\hline Mean & & 6.33 & 5.935 & 6.646 & 5.677 \\
\hline Standard Deviation & & .596 & .911 & .483 & 1.135 \\
\hline
\end{tabular}

Note. Loadings <.3 have been suppressed, in accordance with Burt and Banks' (1947) formula.

$\mathrm{KMO}=.820$. Bartlett's sphericity $p<.000$.

Direct oblimin rotation used.

self-determination $(\alpha=.909)$; impact $(\alpha=.830)$ (Table 1). The factor correlations were moderate and all items loaded on the first unrotated factor. Two of the rotated factors show negative loadings. However, all the unrotated factor intercorrelations (Table 5) were both positive and of more modest magnitude than the rotated loadings

(Table 1). This suggests the negative loadings resulted from the oblique rotation used in the factor analysis. I therefore cautiously followed Spreitzer (1995) in constructing a composite measure from all items representing the overall construct of empowerment (mean $=$ 6.162; S.D. $=.58 ; \alpha=.866$ ), although I acknowledge

\section{Table 2}

Factor Solution for Perceived Social Dominance Measure

\begin{tabular}{|c|c|c|c|c|}
\hline \multirow[b]{2}{*}{ Factors } & & \multicolumn{3}{|c|}{ Factor loadings } \\
\hline & & Inequality & $\begin{array}{l}\text { Expatriate } \\
\text { attitudes }\end{array}$ & Equality \\
\hline \multirow{6}{*}{$\begin{array}{l}\text { Inequality (across } \\
\text { the organisation) }\end{array}$} & Local workers are not really treated as the equal of expatriates & .702 & & \\
\hline & Expatriate workers regard themselves as more worthy than local workers & .829 & & \\
\hline & Expatriate workers don't really care about how equal all groups of people are & .780 & & \\
\hline & Expatriate workers are treated as more deserving than others & .838 & & \\
\hline & Around here, some groups of people are quietly regarded as inferior to others & .457 & & \\
\hline & To get ahead in life, some expatriates find it necessary to step on others & .558 & .315 & \\
\hline \multirow{4}{*}{$\begin{array}{l}\text { Expatriate attitudes } \\
\text { toward equality }\end{array}$} & Most expatriates genuinely believe that increased economic equality is a good thing ${ }^{* *}$ & & .832 & \\
\hline & Most expatriates genuinely believe that increased social equality is a good thing ${ }^{* *}$ & & .937 & \\
\hline & Most expatriates genuinely believe that equality is a good thing ${ }^{* *}$ & & .821 & \\
\hline & $\begin{array}{l}\text { If expatriates and locals were treated more equally we would have fewer problems in our } \\
\text { organizational network }\end{array}$ & & .454 & \\
\hline \multirow{2}{*}{$\begin{array}{l}\text { Equality (across the } \\
\text { organization) }\end{array}$} & In this organizational network, all groups of people are regarded as equal ${ }^{\star *}$ & & & .628 \\
\hline & All workers, whether expatriate or local, are treated equally ${ }^{* *}$ & & & .978 \\
\hline Eigenvalue & & 5.232 & 2.090 & 1.155 \\
\hline$\%$ Variance & & 43.596 & 17.420 & 9.621 \\
\hline Total Variance & & 43.596 & 61.016 & 70.637 \\
\hline Cronbach's Alpha & & .881 & .839 & .813 \\
\hline Mean & & 4.35 & 2.818 & 3.463 \\
\hline Standard Deviation & & 1.339 & .979 & 1.591 \\
\hline
\end{tabular}


Table 3

Factor Solution for Social Identity Measure

\begin{tabular}{|c|c|c|c|}
\hline \multirow[b]{2}{*}{ Factors } & & \multicolumn{2}{|c|}{ Factor loadings } \\
\hline & & $\begin{array}{l}\text { Positive } \\
\text { Filipino } \\
\text { identity }\end{array}$ & $\begin{array}{l}\text { Self- } \\
\text { categorisation }\end{array}$ \\
\hline \multirow[t]{6}{*}{ Positive Filipino identity } & I have little respect for Filipinos ${ }^{* *}$ & .858 & \\
\hline & I dislike being Filipino ${ }^{* *}$ & .814 & \\
\hline & I would like to continue working with Filipinos & .776 & \\
\hline & I feel good about being Filipino & .729 & \\
\hline & I think Filipinos have little to be proud of ${ }^{* *}$ & .469 & \\
\hline & I would rather not tell that I am Filipino** & .437 & \\
\hline \multirow[t]{3}{*}{ Self-categorisation } & I am like other Filipinos & & .663 \\
\hline & Being Filipino is an important reflection of who I am & & .640 \\
\hline & I identify with other Filipinos & & .481 \\
\hline Eigenvalues & & 5.280 & 1.067 \\
\hline$\%$ Variance & & 52.804 & 10.665 \\
\hline Total Variance & & 52.804 & 63.469 \\
\hline Cronbach's Alpha & & .853 & .698 \\
\hline Mean & & 6.288 & 5.502 \\
\hline Standard Deviation & & 1.019 & 1.205 \\
\hline \multicolumn{4}{|c|}{$\begin{array}{l}\text { Note. Item "I would rather belong to another ethnic group (other than Filipino)" removed from factor solution as it cross-loaded } \\
(>.4) \text { on to more than one factor. }\end{array}$} \\
\hline \multicolumn{4}{|c|}{$\mathrm{KMO}=.877$. Bartlett's sphericity $p<.000$} \\
\hline \multicolumn{4}{|l|}{ Direct oblimin rotation used. } \\
\hline${ }^{* *}$ Item reverse scored & & & \\
\hline
\end{tabular}

such a composite is only modestly supported given these findings.

Perceived social dominance. The analysis resulted in three meaningful factors, ${ }^{4}$ which in Table 2 I have labeled 'inequality' ( $\alpha=.881)$, 'expatriate attitudes' $(\alpha=.839)$, and 'equality' $(\alpha=.813)$.

Social identity. The analysis found 2 factors, which in Table 3 I have labeled 'positive Filipino identity' $(\alpha=.853)$; and self-categorisation $(\alpha=.698)$. It appears that two of the original factors reported by Ellemers, et al. (1999) ('group self-esteem' and 'commitment to the group') have collapsed into a single underlying 'positive Filipino identity' factor in this study (Table 3).

While this factor structure differs from that found by Ellemers, et al. (1999), the correlation between the two extracted factors (.601) affirms social identity as an overarching construct in the present context (mean $=6.08$; S.D. $=.971 ; \alpha=.880$ ).

Organisational justice. The three factors found (Table 4) matched those reported by both Niehoff and Moorman (1993) and Spreitzer (1995); interactional justice $(\alpha=$ $.948)$; procedural justice $(\alpha=.951)$ and distributive justice $(\alpha=.810)$. The factor correlations in this sample are moderate, indicating neither multicollinearity nor lack of cohesion amongst the factors. As discussed in relation to the empowerment factor solution above, and for the same reasons, I interpreted the negative factor loadings for the procedural justice items as an artifact of the oblique rotation used. All items in the original measure also loaded on the first unrotated factor, indicating shared variance with an overall underlying construct of organisational justice $($ mean $=5.835 ;$ S.D. $=.781 ; \alpha=.950)$.
Social desirability. KMO (.539) and Bartlett's sphericity $(p<.004)$ test results indicated the social desirability data was marginal for factor analysis. ${ }^{5}$ The initial communalities were low (five of the six $<.160$ ) and reliability was poor $(\alpha=.464)$. The responses to this measure did not match the expected pattern, for example, on one item, "I am always courteous, even to people who are disagreeable," almost everyone strongly agreed, indicating almost universal strong social desirability bias, according to the norms of the measure (Crowne \& Marlowe, 1960). I believe this reflects Filipino cultural preferences regarding maintaining social harmony (Sison, 1999), more than a tendency or bias to give socially desirable answers in a survey. Given these significant validity issues, this measure was not used further.

\section{Correlation Analyses}

The most striking features in Table 5 are the moderate but statistically significant correlations found between work justice as a whole, and all four facets of empowerment (competence $=.325, p<.01$; self-determination $=.482$, $p<.01$; meaning $=.382, p<.01$; impact $=.477, p<$ $.01)$.

Numerical ratio and salary ratio had both insufficient spread and a large number of missing values. No significant correlations between level of education or gender and any of the target variables were observed. Hence these four variables were omitted from both Table 5 and further analysis.

\section{The Predictors of Empowerment: Regression Analyses}

What predicts employees' sense of competence? Respondents' perceptions that expatriates believed in equality in their workplace were uniquely associated with feeling 
Table 4

Factor Solution for Organizational Justice Measure

\begin{tabular}{|c|c|c|c|c|}
\hline \multirow[b]{2}{*}{ Factors } & \multirow[b]{2}{*}{ "My manager/supervisor..." } & \multicolumn{3}{|c|}{ Factor loadings } \\
\hline & & $\begin{array}{l}\text { Interactional } \\
\text { justice }\end{array}$ & $\begin{array}{l}\text { Procedural } \\
\text { justice }\end{array}$ & $\begin{array}{l}\text { Distributive } \\
\text { justice }\end{array}$ \\
\hline \multirow[t]{9}{*}{ Interactional justice } & ... takes account of my needs when handling a problem & .874 & & \\
\hline & ... treats me fairly & .856 & & \\
\hline & ... treats me with politeness & .848 & & \\
\hline & ... considers my views when decisions are made about handling a problem & .802 & & \\
\hline & ... treats me with sensitivity when I ask questions & .768 & & \\
\hline & ... tries hard to be fair to me & .692 & & \\
\hline & ... listens to my personal concerns & .655 & & \\
\hline & ... shows concern for my rights & .628 & -.309 & \\
\hline & $\ldots$ is honest with me & .625 & & \\
\hline \multirow[t]{6}{*}{ Procedural justice } & ... gives me an explanation for decisions & & -.903 & \\
\hline & ... provides explanations for why changes take place & & -.886 & \\
\hline & ... gives adequate explanations and reasons for decisions/changes & & -.877 & \\
\hline & ... seems sincere when explaining reasons for particular decisions/changes & & -.849 & \\
\hline & ... explains how changes will take place & & -.820 & \\
\hline & $\begin{array}{l}\text {... is honest and candid regarding reasons for decisions/changes made } \\
\text { "I am satisfied with..." }\end{array}$ & & -.637 & \\
\hline \multirow[t]{4}{*}{ Distributive justice } & ... my job all in all & & & .894 \\
\hline & ... my current job assignments & & & .762 \\
\hline & ... my relationships with other employees & & & .657 \\
\hline & ... the opportunities for promotion I have in my organizational network & & & .523 \\
\hline Eigenvalue & & 10.794 & 2.094 & 1.602 \\
\hline$\%$ Variance & & 56.810 & 11.023 & 8.429 \\
\hline Total Variance & & 56.810 & 67.833 & 76.262 \\
\hline Cronbach's Alpha & & .948 & .951 & .810 \\
\hline Mean & & 5.95 & 5.983 & 5.565 \\
\hline Standard Deviation & & .874 & .848 & 1.012 \\
\hline
\end{tabular}

Note. Item "I am satisfied with ... my pay" was removed from factor solution as it cross-loaded ( $>$.4) on to more than one factor.

$\mathrm{KMO}=.894$. Bartlett's sphericity $p<.000$.

Direct oblimin rotation used.

more competent in their work (part $\mathrm{r}^{2}=.057 ; p<.05$ ). Being older ( part $\mathrm{r}^{2}=.043 ; p<.1$ ) and perceiving higher levels of distributive justice (part $\mathrm{r}^{2}=.034 ; p<.1$ ) were also uniquely related to respondents' sense of competence. The overall model tested $(F[5,65]=4.058 ; p=.003)$ accounted for .179 (adjusted $R^{2}$ ) of the total variance in competence (Table 6).

What predicts employees' sense of self-determination? Being treated fairly in personal interactions (interactional justice) was uniquely associated with a sense of selfdetermination (part $\mathrm{r}^{2}=.034 ; p<.1$ ). Receiving just rewards (distributive justice) also contributed to this facet of empowerment (part $\left.\mathrm{r}^{2}=.033 ; p<.1\right)$. The overall model tested $(F[4,69]=7.062 ; p<.001)$ accounted for .249 (adjusted $R^{2}$ ) of the total variance in self-determination (Table 6).

What predicts employees' sense of meaning? Only perceptions of just reward systems (distributive justice) were uniquely associated with respondents' sense of meaning in their work ( part $\left.\mathrm{r}^{2}=.051 ; p<.05\right)$. The overall model tested $(F[8,59]=3.917 ; p=.001)$ accounted for .258 (adjusted $R^{2}$ ) of the total variance in meaning (Table 6).
What predicts employees'sense of impact? Having a sense of positive Filipino identity was uniquely associated with feeling that you have impact on your work ( $p a r t r^{2}=.101$; $p<.001$ ), as were perceptions of interactional justice (part $\left.\mathrm{r}^{2}=.042 ; p<.05\right)$. The overall model tested $(F[6,63]=$ 9.211; $p<.001$ ) accounted for .417 (adjusted $R^{2}$ ) of the total variance in impact (Table 6).

What predicts empowerment as a whole? Being older was most strongly associated with feeling more empowered (part $\left.\mathrm{r}^{2}=.097 ; p<.01\right)$, followed by perceptions of interactional justice (part $\left.\mathrm{r}^{2}=.052 ; p<.05\right)$ and expatriate attitudes towards equality ( part $\mathrm{r}^{2}=.040 ; p<.05$ ). The overall model tested $(F[7,59]=6.564 ; p<.001)$ accounted for .371 (adjusted $R^{2}$ ) of the total variance in empowerment (Table 6).

\section{Post Hoc Analyses}

The finding that positive Filipino identity (a facet of social identity) predicted separate facets of empowerment, but not empowerment as a whole (Table 6), suggests that a moderation effect may be in play. Could positive Filipino identity moderate the relationship between interactional justice and empowerment? 
Table 5

Correlation Matrix

\begin{tabular}{|c|c|c|c|c|c|c|c|c|c|c|c|c|c|c|c|c|}
\hline & 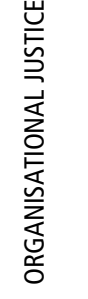 & 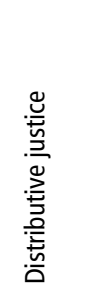 & 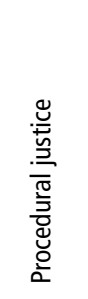 & 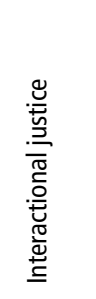 & 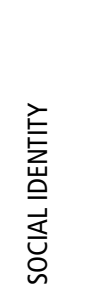 & 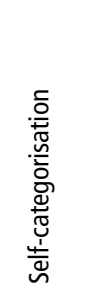 & 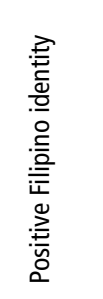 & $\begin{array}{l}\frac{\vec{z}}{\bar{g}} \\
\frac{\bar{z}}{\mathrm{z}}\end{array}$ & 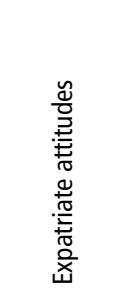 & 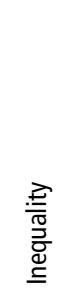 & 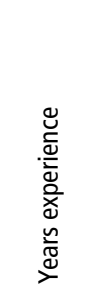 & 莛 & $\begin{array}{l}\underset{\widetilde{\sigma}}{\tilde{E}} \\
\underline{\underline{\xi}}\end{array}$ & 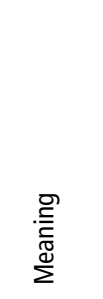 & 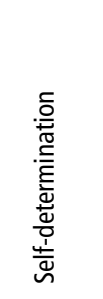 & $\begin{array}{l}\text { प्ّँّ } \\
\text { 产 } \\
\text { 产 }\end{array}$ \\
\hline $\begin{array}{l}\text { EMPOWERMENT } \\
\text { Competence } \\
\text { Self-determination } \\
\text { Meaning } \\
\text { Impact }\end{array}$ & $\begin{array}{l}.538^{* *} \\
.325^{* *} \\
.482^{* *} \\
.382^{* *} \\
.477^{* *}\end{array}$ & $\begin{array}{l}.513^{* *} \\
.379^{* *} \\
.406^{* *} \\
.450^{* *} \\
.513^{* *}\end{array}$ & $\begin{array}{l}.402^{* *} \\
.277^{* *} \\
.345^{* *} \\
.306^{* *} \\
.264^{*}\end{array}$ & $\begin{array}{l}.488^{* *} \\
.243^{*} \\
.451^{* *} \\
.293^{* *} \\
.462^{* *}\end{array}$ & $\begin{array}{l}.302^{* *} \\
.402^{* *} \\
.538^{* *}\end{array}$ & $\begin{array}{l}.362^{* *} \\
.333^{* *}\end{array}$ & $\begin{array}{l}.254^{*} \\
.292^{* *} \\
.525^{* *}\end{array}$ & $\begin{array}{l}-.390^{* *} \\
-.382^{* *} \\
-.372^{* *} \\
-.410^{* *}\end{array}$ & $\begin{array}{l}-266^{*} \\
-.318^{* *} \\
-.281^{*} \\
-.307^{* *}\end{array}$ & & $\begin{array}{l}.316^{* *} \\
.336^{* *} \\
.259^{*} \\
.319^{* *}\end{array}$ & $\begin{array}{l}.311^{* *} \\
.276^{*} \\
.219^{*} \\
.307^{* *}\end{array}$ & $\begin{array}{l}.866^{* *} \\
.540^{* *} \\
.479^{* *} \\
.493^{* *}\end{array}$ & $\begin{array}{l}.666^{* *} \\
.411^{* *} \\
.336^{* *}\end{array}$ & $\begin{array}{l}.750^{* *} \\
.322^{* *}\end{array}$ & $.684^{* *}$ \\
\hline
\end{tabular}

Age

Years experience

\begin{tabular}{|c|c|c|}
\hline $\begin{array}{l}\text { Inequality } \\
\text { Expatriate attitudes } \\
\text { Equality }\end{array}$ & $\begin{array}{l}-.302^{* *} \\
-.401^{* *}\end{array}$ & $\begin{array}{l}-.269^{*} \\
-.280^{*} \\
-.471^{* *}\end{array}$ \\
\hline $\begin{array}{l}\text { SOCIAL IDENTITY } \\
\text { Positive Filipino identity } \\
\text { Selffcrategrisation }\end{array}$ & $.238^{*}$ & $\begin{array}{l}.430^{* *} \\
.352^{* *} \\
39 * *\end{array}$ \\
\hline Self-categorisation & $.254^{*}$ & $.397^{* *}$ \\
\hline $\begin{array}{l}\text { Interactional justice } \\
\text { Procedural justice } \\
\text { Distributive justice }\end{array}$ & $\begin{array}{l}.924^{* *} \\
.835^{* *} \\
.779^{* *}\end{array}$ & $\begin{array}{l}.607^{* * *} . \\
. * 0^{* *}\end{array}$ \\
\hline
\end{tabular}

Note. All nonsignificant coefficients were omitted. Coefficients significant at $p<.01$ in bold.

Headings in ALL CAPS designate composite variables.

${ }^{* *} p<0.01 .{ }^{*} p<0.05$ 
Table 6

Significant Predictors of Facets of Empowerment (Competence, Meaning, Self-determination \& Impact) as well as EMPOWERMENT as a whole

\begin{tabular}{|c|c|c|c|c|c|c|}
\hline \multicolumn{2}{|c|}{ Significant predictor variables } & \multicolumn{2}{|c|}{ Justice } & \multirow{2}{*}{$\begin{array}{l}\text { Identity } \\
\text { Positive } \\
\text { Filipino } \\
\text { identity }\end{array}$} & \multirow{2}{*}{$\begin{array}{l}\text { Dominance } \\
\text { Expatriate } \\
\text { attitudes }\end{array}$} & \multirow{2}{*}{$\begin{array}{c}\text { Demographics } \\
\text { Age }\end{array}$} \\
\hline & & $\begin{array}{l}\text { Distributive } \\
\text { justice }\end{array}$ & $\begin{array}{l}\text { Interactional } \\
\text { justice }\end{array}$ & & & \\
\hline \multicolumn{7}{|l|}{ Dependent variables } \\
\hline \multirow[t]{4}{*}{ Competence } & $\beta$ & .245 & & & -.251 & .215 \\
\hline & Std. Error & .084 & & & .069 & .007 \\
\hline & $t$ & $1.709 \dagger$ & & & $-2.204^{*}$ & $.925 \dagger$ \\
\hline & Part $r^{2}$ & .034 & & & .057 & .043 \\
\hline \multirow[t]{4}{*}{ Self-determination } & $\beta$ & .256 & .275 & & & \\
\hline & Std. Error & .098 & .127 & & & \\
\hline & $t$ & $1.793 \dagger$ & $1.809 \dagger$ & & & \\
\hline & Part $r^{2}$ & .033 & .034 & & & \\
\hline \multirow[t]{4}{*}{ Meaning } & $\beta$ & .307 & & & & \\
\hline & Std. Error & .076 & & & & \\
\hline & $t$ & $2.138^{*}$ & & & & \\
\hline & Part $r^{2}$ & .051 & & & & \\
\hline \multirow[t]{4}{*}{ Impact } & $\beta$ & .248 & .295 & .356 & & \\
\hline & Std. Error & .151 & .193 & .121 & & \\
\hline & $t$ & $1.926 \dagger$ & $2.229^{*}$ & $3.456^{* * *}$ & & \\
\hline & Part $r^{2}$ & .031 & .042 & .101 & & \\
\hline \multirow[t]{4}{*}{ EMPOWERMENT } & $\beta$ & & .331 & & -.212 & .323 \\
\hline & Std. Error & & .102 & & .066 & .006 \\
\hline & $t$ & & $2.321^{*}$ & & $-2.034^{*}$ & $3.187^{* *}$ \\
\hline & Part $^{2} \mathrm{r}$ & & .052 & & .040 & .097 \\
\hline
\end{tabular}

Note. All nonsignificant coefficients were omitted. Coefficients significant at $p<.01$ in bold.

Headings in ALL CAPS designate composite variables.

${ }^{* * *} p<.001 .{ }^{* *} p<.01 .{ }^{*} p<.05 . \dagger p<.1$.

Protocol for moderation exploration. Suitability for moderation analysis was verified by checking the univariate normality, bivariate homoscedascity and bivariate linearity of each variable. Univariate correlations between the parent variables (interactional justice, distributive justice and positive Filipino identity) were also examined. Multicollinearity and multivariate normality, homoscedascity and linearity were assessed to be satisfactory. Both the parent variable and the moderator variable were centered before entry to the analysis. The parent variable and the potential moderator were entered together into the first step of the analysis. The product of the centered parent and moderator variables was entered in to the second step of the analysis (Jose, 2008).

Does positive Filipino identity moderate the relationship between interactional justice and empowerment? As Filipino identity becomes more positive, the relationship between interactional justice and empowerment becomes weaker, reflected in the relatively shallower slope of the line in where positive Filipino identity is high (Jose, 2008). The model including the product of positive Filipino identity and interactional justice ( $F$ change $[1,74]=4.332 ; p=.041)$ explained significantly more variance (adjusted $R^{2}=.294$ ) in impact than the simple combination of positive Filipino identity and interactional justice $\left(F\right.$ change $[2,75]=14.741 ; p<.001$; adjusted $R^{2}=$ $.263)$.

\section{Overall pattern of observed relationships}

Figure 2 graphically shows the observed significant relationships from Table 6 between the predictor variables and (a) the components of empowerment (dotted lines), and (b) empowerment as a whole (solid lines). Standardised beta weights are indicated on the relevant line in the model. Additionally, the moderating influence of positive Filipino identity on the relationship between interactional justice and empowerment is shown with the irregularly dashed line.

\section{Discussion}

\section{Key findings}

The pervasive impact of justice on empowerment. Perceptions of justice had by far the most numerous effects on empowerment. The priority of interactional justice over other forms of justice in predicting empowerment is 


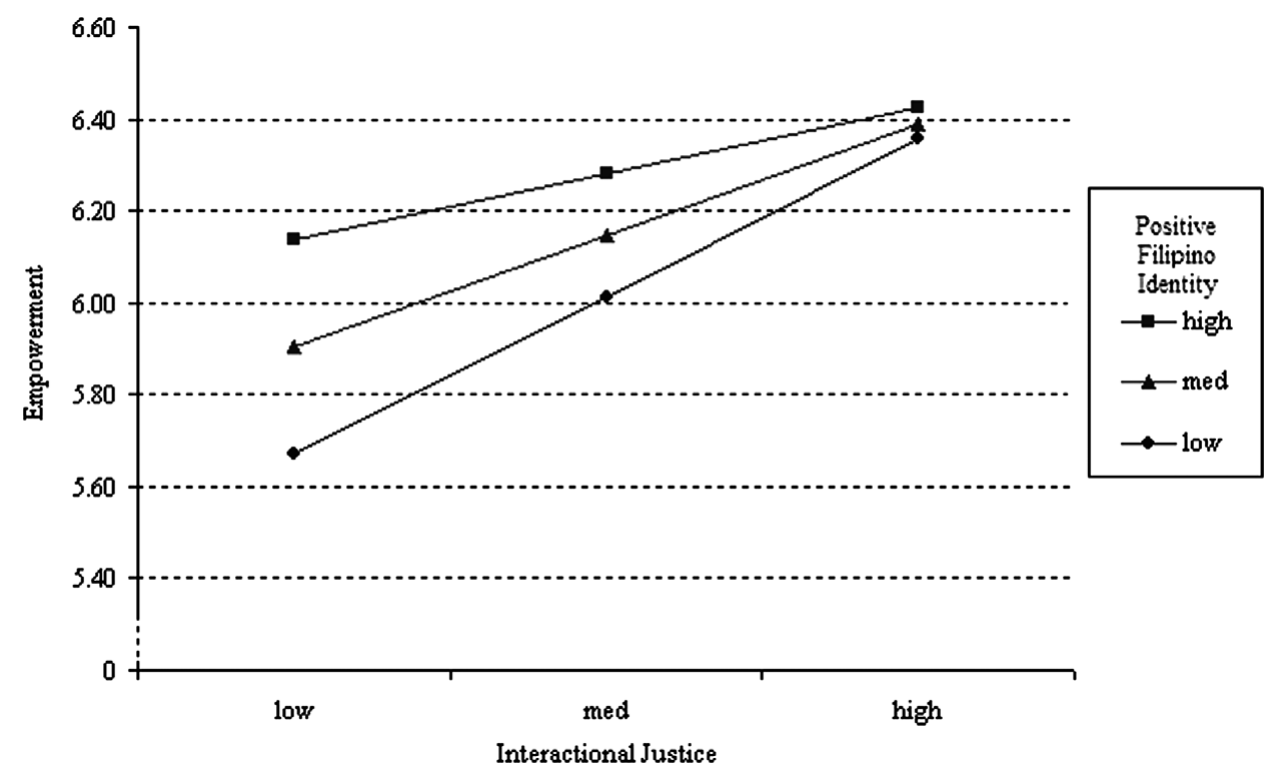

\section{Figure 1}

Moderation of the relationship between interactional justice and empowerment by positive filipino identity.

striking (Figure 2), supporting prior observations that interpersonal harmony may be more important than distributive justice in collectivistic societies (Beugr, 2002; Crosby, 1984) such as the Philippines. ${ }^{6}$
Consistent with other research (Carr, et al., 1998; MacLachlan, et al., 2010; McAuliffe, et al., 2009), higher levels of distributive justice were related positively to all aspects of empowerment amongst Filipino aid employees

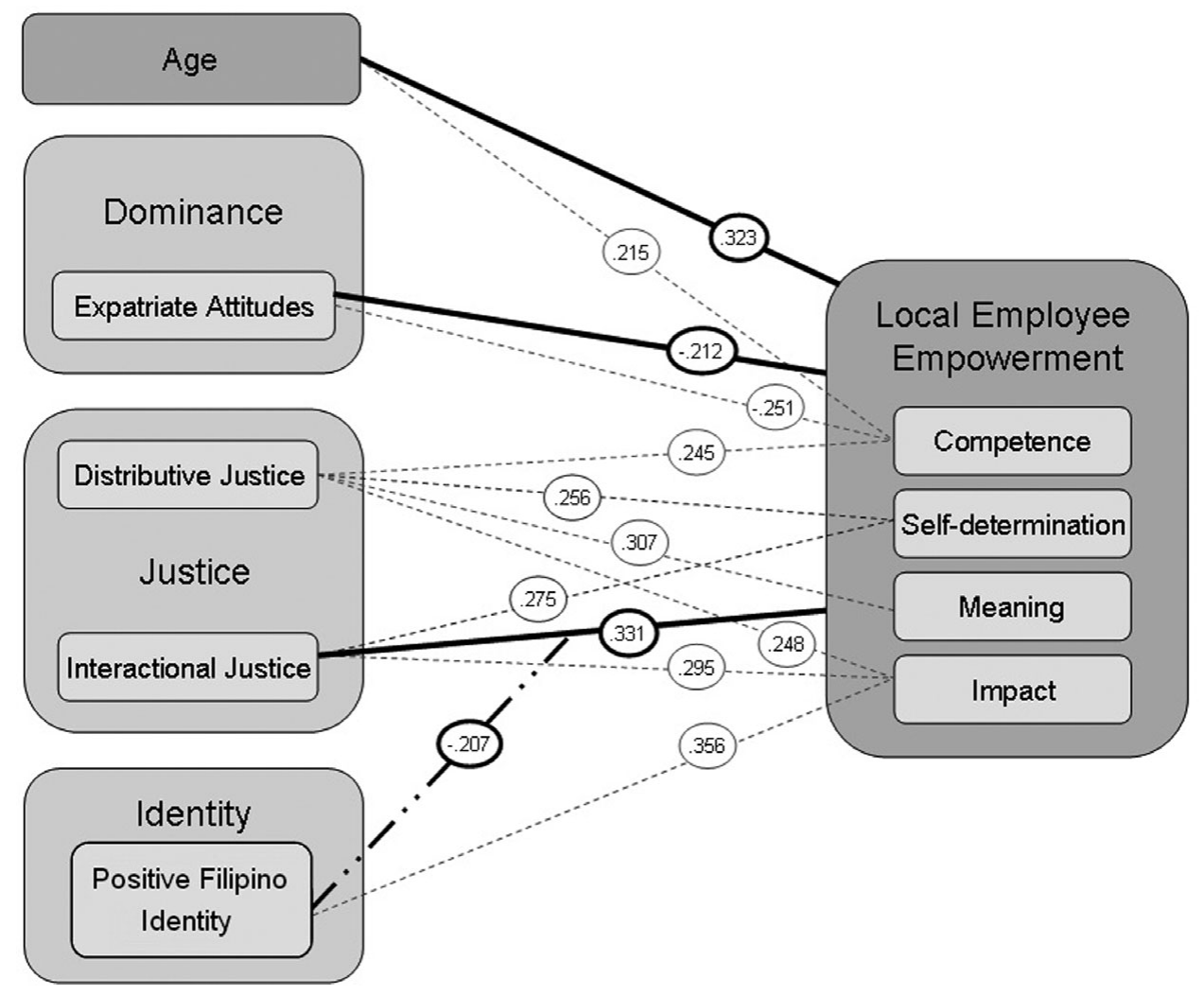

Figure 2

Observed predictors of empowerment and its components

Note. Solid lines = main effects; Dashed lines = component effects; Irregularly dashed line = moderation effect 
(Table 6; Figure 2). This adds to the evidence linking justice with satisfaction, effectiveness and productivity (McAuliffe, et al., 2009; McWha, 2010). However, distributive justice did not predict empowerment as a whole (Table 6). This is somewhat perplexing, and is perhaps a methodological artifact, given the modest strength of the results in terms of effect sizes and statistical significance. Research with larger samples could help to clarify this finding.

The absence of any significant unique relationships between procedural justice and empowerment is intriguing and suggests further research would be useful. Perhaps transparent process is less salient in the Filipino context, or is less important than being treated fairly in personal interactions.

The significance of age and experience. Age closely followed interactional justice as a significant predictor of empowerment (see Figure 2). As expected (Kanter, 1979; Spreitzer, et al., 1997), older employees with longer tenure felt more empowered. Given the high correlation between age and years experience in the aid and development sector (.801), this seems likely to reflect mainly the greater competence that experience brings.

How social identity contributes to empowerment in the workplace. The general prediction arising from social identity theory is that positive social identity should give rise to higher levels of empowerment (Tajfel \& Turner, 2004). This is broadly supported by the positive relationships observed between these constructs in the present study (Table 5). More specifically, a significant link between positive Filipino identity and a sense of having an impact in their workplace (Figure 2) was observed. Positive Filipino identity was also found to moderate the influence of interactional justice on empowerment (Figure 1; Figure 2); those with a stronger Filipino identity were less negatively affected by injustice in personal interactions. Given this moderation effect was observed in a sample who reported generally strong Filipino identity $($ mean $=6.288$; S.D. $=1.019)$, the converse implication may be more disturbing: Employees with a weaker sense of Filipino identity may be particularly vulnerable to disempowerment as a result of unfair interpersonal interactions.

Although positive Filipino identity, a component of social identity, was the strongest predictor of employee's sense of impact $(\beta=.356 ; p<.001)$ it failed to emerge as a significant direct predictor of empowerment more generally (Table 6). This may be because its influence is mostly indirect, moderating the way other antecedents (for example interactional justice) affect empowerment. Alternatively this may reflect weakness in the composite empowerment variable in this study.

How social dominance contributes to empowerment in the workplace. Social dominance theory predicts that employees who perceive their organisational network to be hierarchy-enhancing will experience less empowerment than those in hierarchy-attenuating contexts (Sidanius, et al., 2004). There is some support for this in the negative correlations between the various aspects of perceived social dominance and aspects of empowerment (Table 5). However, social dominance as a coherent construct is not well supported in the present study. This was somewhat surprising given the comprehensive effects of social hierarchies documented elsewhere (Goodwin \& Operario, 1998; Pratto, et al., 2000), including in the aid and development context (MacLachlan, et al., 2010). Perhaps the items measuring perceptions of (in)equality were more difficult to estimate accurately compared with those items referencing expatriates' attitudes.

What was clear was that where local employees perceived expatriate attitudes towards equality to be less negative, they felt more empowered (Figure 2). More specifically, perceptions of expatriate beliefs about equality have the potential to impact local employees' sense of competence at work.

How the Philippine context affected the constructs measured in this study. Empowerment and its four components (competence, self-determination, meaning and impact) were supported strongly by the obtained factor solution. It may therefore be meaningful to discuss empowerment in the Philippines in the terms outlined by Spreitzer (1995; 2008). Likewise, the structure of justice as distributive, procedural and interactional justice (CohenCharash \& Spector, 2001; Niehoff \& Moorman, 1993) was supported in this Philippine context. Social identity also appears to be validated in the present context, although the distinction between self-esteem and group commitment (Ellemers, et al., 1999) was not supported.

However, contrary to expectations about the stability of social dominance across cultures (Pratto, et al., 2000), the structure of perceived social dominance as a coherent unidimensional construct was not supported. Instead, three clear factors (inequality, expatriate attitudes and equality) were observed in the present study. It may be that the rewording of items in this measure which took place in order to focus respondents on expatriatelocal dynamics in their organisational network caused this change in the observed factor structure of perceived social dominance.

\section{Policy Implications}

A number of tentative implications for development practice can be identified. The significant role of justice perceptions supports calls for attention to pay equity and wider issues of justice made previously by a number of researchers (Carr, et al., 1998; MacLachlan, et al., 2010; McAuliffe, et al., 2009; McWha, 2010). Training for both expatriates and locals regarding the importance of justice in interpersonal interactions could be helpful. Further, expatriate attitudes towards equality clearly matter. Thus raising awareness of this during expatriate preparation for overseas assignments could benefit local employees. 
Lastly, the potential buffer effect of strong Filipino identity against injustice provides a rationale for efforts that aim to strengthen positive identity amongst local employees in aid organisations in the Philippines.

\section{Limitations and Improvements}

Little is known about the representativeness or response rate of the sample. A degree of self-selection is likely to have occurred. The small sample size means both the factor and regression analyses should be treated cautiously as exploratory findings. Researchers based in the Philippines may have been able to take advantage of more robust sampling techniques including distributing fixed numbers of surveys to potential respondents at their physical workplace. As with all self-report-based studies, there is likely to be a difference between how respondents actually feel and how they report their feelings. Common method variance may have been partly responsible for the relationships observed between the variables, ${ }^{7}$ although the generally very high levels of reliability observed on all measures may mitigate against this possibility (Laschinger, Finegan, Shamian, \& Wilk, 2004).

Differences between English and Tagalog survey respondents were observed on 8 of the 64 items. Given both the large number of potential items, and the small number of respondents who responded in Tagalog $(N=12)$, the observed differences seem relatively unconcerning. The rigorous process of translation, back translation and consultation regarding the two language versions of the questionnaire (Brislin, 1980) minimised the possibility of serious confounding as a result of language difference.

\section{Suggestions for Further Research}

First, the importance of interactional justice in comparison with distributive justice in the Philippines and other more collective-oriented societies seems critical. While pay equity is clearly an important issue, the role of justice in interpersonal interactions may be more important than previously thought, and there is little research on the subject within the context of aid work.

Second, the lack of coherence of social dominance in the present study was surprising. In direct contrast to the assertions of Pratto, et al. (2000), social dominance as a theoretical construct fared the least well of all the measures used in the present study. Perhaps hierarchy and patterns of dominance are taken for granted in the Philippines (de Guzman, 2011), or perhaps the construct was poorly operationalised in the present study. In any case, more research is needed to explore whether social dominance theory as constituted elsewhere (Sidanius, et al., 2004) is relevant to aid work in the Philippines.

Third, the potential for aspects of social identity, in particular positive ethnic identity, to buffer the effects of (in)justice is potentially of great interest not only in the Philippines, but in many postcolonial settings. A related issue regarding social identity that the present study did not address revolves around the comparative importance of ethnic versus organisational identity. What happens if local employees feel more attachment to (for example) being Filipino than to being employees of a particular organisation? Further research into the contrasting (or complementary) effects of identification with both local employees' ethnic group and the employing aid organisation would help to shed light on this issue.

\section{Conclusion}

The focus on the provision of decent work for all is enshrined in Millennium Goal 1b (United Nations, 2000). Human dynamics such as dominance, identity and justice influence the achievement of this worthy goal. This study contributes significant new clarity to the ways in which these factors influence workplace empowerment, which is central to the very notion of decent work. Amongst aid sector employees in the Philippines, interactional justice is the single largest contributor to perceptions of empowerment, followed by age and expatriate attitudes towards equality. A strong Filipino identity played the largest role amongst the variables in this study in determining the sense of impact local employees feel they can have in their workplace. Further, when the sense of Filipino identity is positive, interactional justice matters less.

If we are to achieve the maximum progress possible towards the Millennium goals, organisations involved in aid work need to be cognisant of the human dynamics of the workplace. Local employees will increasingly form the bulk of the aid sector workforce and thus their empowerment is critical to maintaining a productive and effective workforce. Treating them fairly and fostering conditions which support a strong sense of social identity are key to achieving the goals of individuals and organisations alike within the broad sweep of efforts to reduce poverty on this planet. 


\section{Appendix}

\section{Questionnaire}

NOTE: This questionnaire is available in Tagalog from the author

The questions below focus on your attitudes and beliefs as an employee in aid/development work in the Philippines. As you answer the questions, think about the relationships, patterns and culture within your organisational network. This is the group of people, both international and local, that you would normally expect to work with in your organisation, partnership or project.

The first set of questions is about how empowered you feel in your organisational network.

Choose the response that best reflects how much you agree with these statements.

1. The work I do is very important to me.

2. My job activities are personally meaningful to me.

3. The work I do is meaningful to me.

4. I am confident about my ability to do my job.

5. I am self-assured about my capabilities to perform my work activities.

6. I have mastered the skills necessary for my job.

7. I have significant autonomy In determining how I do my job.

8. I can decide on my own how to go about doing my work.

9. I have considerable opportunity for independence and freedom in how I do my job.

10. My impact on what happens in my department or workgroup is large. 11. I have a great deal of control over what happens in my department or workgroup.

12. I have significant influence over what happens in my department or workgroup.

$\begin{array}{cc}\text { Strongly } & \\ \text { disagree } & \text { Disagree } \\ 1 & 2 \\ 1 & 2 \\ 1 & 2 \\ 1 & 2 \\ 1 & 2 \\ 1 & 2 \\ 1 & 2 \\ 1 & 2 \\ 1 & 2 \\ 1 & 2 \\ 1 & 2 \\ 1 & 2\end{array}$

$\begin{array}{ccccc}\begin{array}{c}\text { Slightly } \\ \text { disagree }\end{array} & & \begin{array}{c}\text { Slightly } \\ \text { agree }\end{array} & \begin{array}{c}\text { Agree } \\ \text { Strongly } \\ \text { agree }\end{array} \\ 3 & 4 & 5 & 6 & 7 \\ 3 & 4 & 5 & 6 & 7 \\ 3 & 4 & 5 & 6 & 7 \\ 3 & 4 & 5 & 6 & 7 \\ 3 & 4 & 5 & 6 & 7 \\ 3 & 4 & 5 & 6 & 7 \\ 3 & 4 & 5 & 6 & 7 \\ 3 & 4 & 5 & 6 & 7 \\ & 5 & 6 & 7 \\ 3 & 4 & 5 & 6 & 7 \\ 3 & 4 & 5 & 6 & 7 \\ 3 & 4 & 5 & 6 & 7\end{array}$

The next set of questions is about fairness between Filipinos and expatriates in your organisational network. This includes the people you would normally be expected to work with, both local and international, in your organisation, partnership or project.

Choose the response that best reflects how much you agree with these statements.

My manager/supervisor...

13. ... gives me an explanation for decisions.

14. ... seems sincere when explaining reasons for particular decisions/changes.

15. ... provides explanations for why changes take place.

16. ... explains how changes will take place.

17. ... gives adequate explanations and reasons for decisions/changes.

$18 . . .$. is honest and candid regarding reasons for decisions/changes made.

19. ... shows concern for my rights.

20 . ... treats me with sensitivity when I ask questions.

21 . ... considers my views when decisions are made about handling a problem.

22. ... takes account of my needs when handling a problem.

23. ... treats me with politeness.

$24 . .$. treats me fairly.

25. ... listens to my personal concerns.

$26 . . .$. is honest with me.

$27 . .$. tries hard to be fair to me.

\begin{tabular}{|c|c|c|c|c|c|c|}
\hline $\begin{array}{l}\text { Strongly } \\
\text { disagree }\end{array}$ & Disagree & $\begin{array}{l}\text { Slightly } \\
\text { disagree }\end{array}$ & & $\begin{array}{l}\text { Slightly } \\
\text { agree }\end{array}$ & Agree & $\begin{array}{l}\text { Strongly } \\
\text { agree }\end{array}$ \\
\hline 1 & 2 & 3 & 4 & 5 & 6 & 7 \\
\hline 1 & 2 & 3 & 4 & 5 & 6 & 7 \\
\hline 1 & 2 & 3 & 4 & 5 & 6 & 7 \\
\hline 1 & 2 & 3 & 4 & 5 & 6 & 7 \\
\hline 1 & 2 & 3 & 4 & 5 & 6 & 7 \\
\hline 1 & 2 & 3 & 4 & 5 & 6 & 7 \\
\hline 1 & 2 & 3 & 4 & 5 & 6 & 7 \\
\hline 1 & 2 & 3 & 4 & 5 & 6 & 7 \\
\hline 1 & 2 & 3 & 4 & 5 & 6 & 7 \\
\hline 1 & 2 & 3 & 4 & 5 & 6 & 7 \\
\hline 1 & 2 & 3 & 4 & 5 & 6 & 7 \\
\hline 1 & 2 & 3 & 4 & 5 & 6 & 7 \\
\hline 1 & 2 & 3 & 4 & 5 & 6 & 7 \\
\hline 1 & 2 & 3 & 4 & 5 & 6 & 7 \\
\hline 1 & 2 & 3 & 4 & 5 & 6 & 7 \\
\hline
\end{tabular}

I am satisfied with... 


\begin{tabular}{|c|c|c|c|c|c|c|c|}
\hline & $\begin{array}{l}\text { Strongly } \\
\text { disagree }\end{array}$ & Disagree & $\begin{array}{l}\text { Slightly } \\
\text { disagree }\end{array}$ & & $\begin{array}{l}\text { Slightly } \\
\text { agree }\end{array}$ & Agree & $\begin{array}{l}\text { Strongly } \\
\text { agree }\end{array}$ \\
\hline 28. ... my pay. & 1 & 2 & 3 & 4 & 5 & 6 & 7 \\
\hline $\begin{array}{l}29 . . . \text { the opportunities for promotion I have in my organisational } \\
\text { network. }\end{array}$ & 1 & 2 & 3 & 4 & 5 & 6 & 7 \\
\hline 30. ... my relationships with other employees. & 1 & 2 & 3 & 4 & 5 & 6 & 7 \\
\hline 31. ... my current job assignments. & 1 & 2 & 3 & 4 & 5 & 6 & 7 \\
\hline 32. ... my job all in all. & 1 & 2 & 3 & 4 & 5 & 6 & 7 \\
\hline
\end{tabular}

The next set of questions is about your feelings and attitudes in the context of your organisational network.

Choose the response that best reflects how much you agree with these statements.

[SI-33] I think Filipinos have little to be proud of ${ }^{\star}$

[SI-34] I feel good about being Filipino

[SD-43 (T)] I have never intensely disliked anyone.

[SI-35] I have little respect for Filipinos*

[SD-44 (T)] I am always courteous, even to people who are disagreeable.

[SI-36] I would rather not tell that I am Filipino*

[SI-37] I identify with other Filipinos

[SD-45 (F)] I sometimes feel resentful when I don't get my way.

[SD-46 (F)] There have been times when I felt like rebelling against people

in authority even though I knew they were right.

[SI-38] I am like other Filipinos

[SI-39] Being Filipino is an important reflection of who I am

[SD-47 (F)] There have been times when I was quite jealous of the good

fortune of others

[SI-40] I would like to continue working with Filipinos

[SI-41] I dislike being Filipino*

[SD-48 (F)] I am sometimes irritated by people who ask favors of me

[SI-42] I would rather belong to another ethnic group (other than Filipino) ${ }^{*}$

\begin{tabular}{|c|c|c|c|c|c|c|}
\hline $\begin{array}{l}\text { Strongly } \\
\text { disagree }\end{array}$ & Disagree & $\begin{array}{l}\text { Slightly } \\
\text { disagree }\end{array}$ & & $\begin{array}{l}\text { Slightly } \\
\text { agree }\end{array}$ & Agree & $\begin{array}{l}\text { Strongly } \\
\text { agree }\end{array}$ \\
\hline 1 & 2 & 3 & 4 & 5 & 6 & 7 \\
\hline 1 & 2 & 3 & 4 & 5 & 6 & 7 \\
\hline 1 & 2 & 3 & 4 & 5 & 6 & 7 \\
\hline 1 & 2 & 3 & 4 & 5 & 6 & 7 \\
\hline 1 & 2 & 3 & 4 & 5 & 6 & 7 \\
\hline 1 & 2 & 3 & 4 & 5 & 6 & 7 \\
\hline 1 & 2 & 3 & 4 & 5 & 6 & 7 \\
\hline 1 & 2 & 3 & 4 & 5 & 6 & 7 \\
\hline 1 & 2 & 3 & 4 & 5 & 6 & 7 \\
\hline 1 & 2 & 3 & 4 & 5 & 6 & 7 \\
\hline 1 & 2 & 3 & 4 & 5 & 6 & 7 \\
\hline 1 & 2 & 3 & 4 & 5 & 6 & 7 \\
\hline 1 & 2 & 3 & 4 & 5 & 6 & 7 \\
\hline 1 & 2 & 3 & 4 & 5 & 6 & 7 \\
\hline 1 & 2 & 3 & 4 & 5 & 6 & 7 \\
\hline 1 & 2 & 3 & 4 & 5 & 6 & 7 \\
\hline
\end{tabular}

[ ${ }^{*}$ reverse coded]

Please think again about local and international colleagues and the relationships you have within your organisational network. This includes the people you would normally be expected to work with, both international and local, in your organisation, partnership or project.

Beside each statement, select a number from ' 1 ' to ' 7 ' which represents how strongly people in your organisational network would agree or disagree with the statement.

In this network:

[49] Local workers are not really treated as the equal of expatriates.

[50] Expatriate workers regard themselves as more worthy than local workers.

[51] Expatriate workers don't really care about how equal all groups of people are.

[52] Expatriate workers are treated as more deserving than others.

[53] It is not a problem if our expatriate colleagues have more of a chance in life than others.

[54] Around here, some groups of people are quietly regarded as inferior to others.

[55] To get ahead in life, some expatriates find it necessary to step on others.

[56] Most expatriates genuinely believe that increased economic equality is a good thing. ${ }^{*}$

[57] Most expatriates genuinely believe that increased social equality is a good thing."

[58] Most expatriates genuinely believe that equality is a good thing. *

[59] If expatriates and locals were treated more equally we would have fewer problems in our organisational network. *

[60] In this organisational network, all groups of people are regarded as equal. ${ }^{*}$

[61] All workers, whether expatriate or local, are treated equally.

[62] Most expatriates genuinely believe that it is important to treat other groups of people as equals. ${ }^{*}$

\begin{tabular}{|c|c|c|c|c|c|c|}
\hline $\begin{array}{l}\text { Strongly } \\
\text { disagree }\end{array}$ & Disagree & $\begin{array}{l}\text { Slightly } \\
\text { disagree }\end{array}$ & & $\begin{array}{l}\text { Slightly } \\
\text { agree }\end{array}$ & Agree & $\begin{array}{l}\text { Strongly } \\
\text { agree }\end{array}$ \\
\hline 1 & 2 & 3 & 4 & 5 & 6 & 7 \\
\hline 1 & 2 & 3 & 4 & 5 & 6 & 7 \\
\hline 1 & 2 & 3 & 4 & 5 & 6 & 7 \\
\hline 1 & 2 & 3 & 4 & 5 & 6 & 7 \\
\hline 1 & 2 & 3 & 4 & 5 & 6 & 7 \\
\hline 1 & 2 & 3 & 4 & 5 & 6 & 7 \\
\hline 1 & 2 & 3 & 4 & 5 & 6 & 7 \\
\hline 1 & 2 & 3 & 4 & 5 & 6 & 7 \\
\hline 1 & 2 & 3 & 4 & 5 & 6 & 7 \\
\hline 1 & 2 & 3 & 4 & 5 & 6 & 7 \\
\hline 1 & 2 & 3 & 4 & 5 & 6 & 7 \\
\hline 1 & 2 & 3 & 4 & 5 & 6 & 7 \\
\hline 1 & 2 & 3 & 4 & 5 & 6 & 7 \\
\hline 1 & 2 & 3 & 4 & 5 & 6 & 7 \\
\hline
\end{tabular}


The next two questions ask you to make estimations about your organisational network. This includes the people you would normally be expected to work with, both local and international, in your organisation, partnership or project.

[63] What is the approximate ratio between the numbers of international and local employees in your organisational network? (for example "50\% Filipino:50\% International", or "80\% Filipino: 20\% International")

[64] What is the approximate ratio between Filipino and international salaries in your organisational network? (for example "Filipino 1:1 International" would mean that Filipino and international salaries are about the same, or "Filipino 1:10 International" would mean that Filipino salaries are about $1 / 10^{\text {th }}$ or $10 \%$ of international salaries)

The final set of questions asks about some information about you.

[65] What is your age in years?

[66] What is your gender? Male Female

[67] What is your ethnicity? Filipino Other

[68] What is your job title?

[69] What is your highest qualification?

[70] How many year's experience in the development sector do you have?

Thank you for taking part in this survey.

\section{Acknowledgments}

This paper presents the main findings of a masteral thesis. The author is grateful to Professor Stuart Carr for his guidance and generous supervision throughout the project. The author is also appreciative of the insightful cultural advice provided by Judith Marasigan de Guzman and the assistance she and her associates in Manila, Philippines provided to the author in contacting suitable survey respondents. The peer reviewers' comments on earlier versions of this paper were also very helpful and much appreciated.

\section{Endnotes}

1 A model that fits the data well should have a $\chi^{2} / \mathrm{df}$ ratio of less than 2 and RMSEA values less than .05 (Byrne, 2001). The $\chi^{2} / \mathrm{df}$ ratio of the models tested by Colquitt (2001) ranged from 7.63 to 2.08 in a sample $(N=337)$ of manufacturing employees, and from 4.85 to 1.90 in a sample $(N=301)$ of university students. Root mean square errors of approximation (RMSEA) were all larger than .055 .

2 It had been intended that organisational affiliation would be measured directly, but ethical issues resulted in the removal of this question from the survey. IP address ownership and geographical location do not provide explicit evidence of organisational affiliation, but they do indicate that clustering of respondents at the organisational level is very unlikely in this sample.

3 The factor analysis of the perceived social dominance measure needed to be handled slightly differently. This measure is claimed by its authors to have just one factor (Pratto, et al., 1994), a claim that is based on; (1) a large drop between the first and second eigenvalues under an exploratory principle components analysis of all archival samples; and (2) a satisfactory $\chi^{2} / \mathrm{df}$ ratio (indicator of model fit) for a model with a single underlying construct, tested on the largest $(N=446)$ archival sample using maximum likelihood estimation. However neither the actual eigenvalues nor the item loadings on the single factor were reported in Pratto, et al. (1994). These reported procedures do not appear to constitute a traditional single factor Harman test (Podsakoff, et al., 2003).

4 I initially checked for a single underlying factor structure using the same tests as reported in Pratto, et al. (1994). This analysis resulted in three factors (with eigenvalues of 5.26, 2.108, and 1.218), not the single factor reported in Pratto, et al. (1994). I then tested a model in which all items were based on a single underlying factor using maximum likelihood estimation. The final communalities for 9 of 14 items were less than .5 , indicating that these items shared relatively little variance with the extracted factor. Two of the 14 items were not significantly correlated with the single factor extracted at all. The $\chi^{2} / \mathrm{df}$ ratio was $4.173(p=.000)$, indicating a less than satisfactory fit to the model (Shimizu, Vondracek, \& Schulenberg, 1994). I then proceeded to explore the measure's structure according to my protocol, described above.

5 Social desirability was measured as a continuous variable in order to maintain consistency with the surrounding items in the questionnaire. It was analysed as a dichotomous variable to allow interpretation according to the original instrument's criterion properties (Fischer \& Fick, 1993). In order to check that the observed weakness of the social desirability data was not an artifact of this potentially distorting process, 
factor analysis was also attempted with the continuous social desirability data. The results were similar to that of the dichotomous data presented above. As a further precautionary measure, the item with the highest initial communality ('I sometimes feel resentful when I don't get my way': .241) was examined for correlations with all main variables. No significant correlations were observed ( $p<.05$, one-tailed), providing some reassurance regarding social desirability.

6 It is perhaps important to note that specific relationships between perceptions of pay parity and empowerment were not analysed in this study, as for the respondents, pay is likely to have been conceptually distinct from the broader notion of distributive justice.

7 A Harman test with all perceptual items included resulted in 21 unrotated factors with eigenvalues $>1$. The largest factor accounted for only $24.155 \%$ of the variance in the initial solution. This indicates that common method variance is unlikely to be an issue of concern (Podsakoff, et al., 2003), although it does not eliminate the possibility.

\section{References}

Abrams, D., \& Hogg, M. (1988). Comments on the motivational status of self-esteem in social identity and intergroup discrimination. European Journal of Social Psychology, 18, 317-334.

Adams, J.S. (1965). Inequity in social exchange. In L. Berkowitz (Ed.), Advances in experimental social psychology (Vol. 2, pp. 267-299). New York: Academic Press.

Amiot, C.E., Terry, D.J., Wirawan, D., \& Grice, T.A. (2010). Changes in social identities over time: The role of coping and adaptation processes. British Journal of Social Psychology, 49(4), 803-826.

Aryee, S., \& Chen, Z.X. (2006). Leader-member exchange in a Chinese context: Antecedents, the mediating role of psychological empowerment and outcomes. Journal of Business Research, 59, 793-801.

Avolio, B.J., Zhu, W., Koh, W., \& Bhatia, P. (2004). Transformational leadership and organizational commitment: Mediating role of psychological empowerment and moderating role of structural distance. Journal of Organizational Behavior, 25, 951-968.

Beugr, C.D. (2002). Understanding organizational justice and its impact on managing employees: An African perspective. The International Journal of Human Resource Management, 13(7), 1091-1104.

Bies, R.J. (2005). Are procedural and interactional justice conceptually distinct? In J. Greenberg \& J.A. Colquitt (Eds.), Handbook of organizational justice (pp. 85-112). Mahwah, NJ: Lawrence Erlbaum Associates Inc.

Bond, M.H., \& Hewstone, M. (1988). Social identity theory and the perception of intergroup relations in Hong Kong. International Journal of Intercultural Relations, 12(2), 153-170. doi:10.1016/0147-1767(88)90046-6

Bontempo, R. (1993). Translation fidelity of psychological scales: An item response theory analysis of an IndividualismCollectivism scale. Journal of Cross-Cultural Psychology, 24(2), 149-166.
Brislin, R. (1980). Translation and content analysis of oral and written material. In H.C. Triandis \& J.W. Berry (Eds.), Handbook of crosscultural psychology (Vol. 2, pp. 389-444). Boston: Allyn \& Bacon.

Brown, R. (2000). Social identity theory: past achievements, current problems and future challenges. [Article]. European Journal of Social Psychology, 30(6), 745-778.

Burt, C., \& Banks, C. (1947). A factor analysis of body measurements for British adult males. Annals of Eugenics (Cambridge), 13, 238-256.

Byrne, B.M. (2001). Structural equation modeling with AMOS, EQS, and LISREL: Comparative approaches to testign for the factorial validity of an instrument. International Journal of Testing, 1(1), 55-86.

Carr, S.C., Chipande, R., \& MacLachlan, M. (1998). Expatriate aid salaries in Malawi: A doubly demotivating influence? International Journal of Educational Development, 18(2), 133143.

Carr, S.C., Ehiobuche, I., Rugimbana, R., \& Munro, D. (1996). Expatriates' ethnicity and their effectiveness: 'Similarity attraction' or 'inverse resonance'? Psychology \& Developing Societies, 8, 265-282.

Carr, S.C., McWha, I., MacLachlan, M., \& Furnham, A. (2010). International-local remuneration differences across six countries: Do they undermine poverty reduction work? International Journal of Psychology, 45(5), 321-340.

Coates, K., \& Carr, S.C. (2005). Skilled immigrants and selection bias: A theory-based field study from New Zealand. International Journal of Intercultural Relations, 29(5), 577-599.

Cohen-Charash, Y., \& Spector, P. (2001). The role of justice in organizations: A meta-analysis. Organizational Behavior and Human Decision Processes, 86(2), 278-321.

Colquitt, J.A. (2001). On the dimensionality of organizational justice: A construct validation of a measure. Journal of Applied Psychology, 86(3), 386-400.

Colquitt, J.A., Conlon, D.E., Wesson, M.J., Porter, C.O.L.H., \& Ng, K.Y. (2001). Justice at the millenium: A meta-analytic review of 25 years of organizational justice research. Journal of Applied Psychology, 86(3), 425-445.

Crosby, F. (1984). Relative deprivation in organizational settings. In L.L. Cummings \& B.M. Staw (Eds.), Research in organizational behavior (Vol. 6, pp. 51-93). Greenwich, CT: JAI Press.

Crowne, D.P., \& Marlowe, D. (1960). A scale of social desirability independent of psychopathology. Journal of Consulting Psychology, 24, 349-354.

de Guzman, J.M. (2011). [personal communication].

Doms, M., \& van Avermaet, E. (1985). Social support and minority influence: The innovation effect reconsidered. In G.M.S. Moscovici \& E.V. Avermaet (Eds.), Perspectives on minority influence (pp. 53-74). Cambridge: Cambridge University Press.

Ellemers, N., Kortekaas, P., \& Ouwerkerk, J.W. (1999). Selfcategorisation, commitment to the group and group selfesteem as related but distinct aspects of social identity. European Journal of Social Psychology, 29, 371-389. 
Ergeneli, A., Sag, G., Ari, I., \& Metin, S. (2007). Psychological empowerment and its relationship to trust in immediate managers. Journal of Business Research, 60(1), 41-56.

Essed, P. (2002). Everyday racism. In D.T. Goldberg \& J. Solomos (Eds.), A companion to racial and ethnic studies. Oxford: Blackwell Publishers, Ltd.

Fischer, D.G., \& Fick, C. (1993). Measuring social desirability: Short forms of the Marlowe-Crowne social desirability scale. Educational and Psychological Measurement, 53, 417424.

Goodwin, S.A., \& Operario, D. (1998). Situational power and interpersonal dominance facilitate bias and inequality. Journal of Social Issues, 54(4), 677-698.

Greenberg, J. (1987). A taxonomy of organizational justice theories. The Academy of Management Review, 12(1), 9-22.

Greenberg, J. (1990). Organizational justice: Yesterday, today and tomorrow. Journal of Management, 16(2), 399-432.

Harman, H.H. (1976). Modern factor analysis (3rd ed.). Chicago: The University of Chicago Press.

Hechanova, R.M., Alampay, R.B.A., \& Franco, E.P. (2006). Psychological empowerment, job satisfaction and performance among Filipino service workers. Asian Journal of Social Psychology, 9, 72-78.

Hochwälder, J., \& Brucefors, A.B. (2005). Psychological empowerment at the workplace as a predictor of ill health. Personality and Individual Differences, 39(7), 1237-1248.

Hogg, M., Terry, D.J., \& White, K.M. (1995). A tale of two theories: A critical comparison of identity theory with social identity theory. Social Psychology Quarterly, 58(4), 255269.

Homans, G.C. (1961). Social behavior: Its elemental forms. New York: Harcourt, Brace and World.

House, R.J., Hanges, P.J., Javidan, M., Dorfman, P.W., \& Gupta, V. (Eds.). (2008). Culture, leadership and organizations: The GLOBE study of 62 societies. Thousand Oaks, CA: Sage Publications.

Hui, M.K., Au, K., \& Fock, H. (2004). Empowerment effects across cultures. Journal of International Business Studies, 35(1), 46-60.

Jose, P.E. (2008). ModGraph-I: A programme to compute cell means for the graphical display of moderational analyses: The internet version, Version 2.0. Wellington: Victoria University of Wellington. Retrieved from http://www.victoria. ac.nz/psyc/staff/paul-jose-files/modgraph/modgraph.php

Kanter, R.M. (1979). Power failure in management circuits. Harvard Business Review, 57(4), 65-75.

Kipnis, D., Castell, P., Gergen, M., \& Mauch, D. (1976). Metamorphic effects of power. Journal of Applied Psychology, 61(2), 127-135.

Laschinger, H.K.S., Finegan, J.E., Shamian, J., \& Wilk, P. (2004). A longitudinal analysis of the impact of workplace empowerment on work satisfaction. Journal of Organizational Behavior, 25(4), 527-545.

Latané, B. (1981). The psychology of social impact. American Psychologist, 36(4), 343-356.
MacLachlan, M. (1993). Sustaining human resource development in Africa: The influence of expatriates. Management Learning, 24(2), 167-171.

MacLachlan, M., Carr, S.C., \& McAuliffe, E. (2010). The aid triangle: Recognising the human dynamics of dominance, justice and identity. London: Zed Books.

McAuliffe, E., Manafa, O., Maseko, F., Bowie, C., \& White, E. (2009). Understanding job satisfaction amongst mid-level cadres in Malawi: The contribution of organizational justice. Reproductive Health Matters, 17(33), 80-90.

McWha, I. (2010). What's in a name? Job categorisation, relationship building, and work motivation in aid organizations. $\mathrm{PhD}$ thesis, Massey University, Auckland.

Menon, S.T. (2001). Employee empowerment: An integrative psychological approach. Applied Psychology: An International Review, 50(1), 153-180.

Narayan, D., Pritchett, L., \& Kapoor, S. (2009). Success from the bottom up (Vol. 2). Washington, DC: Palgrave Macmillan.

Niehoff, B.P., \& Moorman, R.H. (1993). Justice as a mediator of the relationship between methods of monitoring and organizational citizenship behavior. Academy of Management Journal, 36(3), 527-556.

Podsakoff, P.M., MacKenzie, S.B., Lee, J., \& Podsakoff, N.P. (2003). Common method biases in behavioral research: A critical review of the literature and recommended remedies. Journal of Applied Psychology, 88(5), 879-903.

Pratto, F., Liu, J.H., Levin, S., Sidanius, J., Shih, M., Bachrach, H., et al. (2000). Social dominance orientation and the legitimization of inequality across cultures. Journal of CrossCultural Psychology, 31(3), 369-409.

Pratto, F., Sidanius, J., Stallworth, L.M., \& Malle, B.F. (1994). Social dominance orientation: A personality variable predicting social and political attitudes. Journal of Personality and Social Psychology, 67(4), 741-763.

Sheldon, K.M., \& Bettencourt, B.A. (2002). Psychological needsatisfaction and subjective well-being within social groups. British Journal of Social Psychology, 41(1), 25-38.

Shimizu, K., Vondracek, F.W., \& Schulenberg, J. (1994). Unidimensionality versus multidimensionality of the Career Decision Scale: A critique of Martin, Sabourin, Laplante, and Coallier. Journal of Career Assessment, 2(1), 1-14.

Sidanius, J., \& Pratto, F. (1993). The inevitability of oppression and the dynamics of social dominance. In P.M. Sniderman, P.E. Tetlock \& E.G. Carmines (Eds.), Prejudice, politics and the American dilemma. Stanford: Stanford University Press.

Sidanius, J., \& Pratto, F. (2003). Social dominance theory and the dynamics of inequality: A reply to Schmitt, Branscombe, \& Kappen and Wilson \& Liu. British Journal of Social Psychology, 42, 207-213.

Sidanius, J., Pratto, F., \& Brief, D. (1993). Group dominance and the political psychology of gender: A cross-cultural comparison. Unpublished manuscript. University of California at Los Angeles.

Sidanius, J., Pratto, F., \& Rabinowitz, J. (1994). Gender, ethnic status and ideological asymmetry: A social dominance perspective. Journal of Cross-Cultural Psychology, 25, 194-216. 
Sidanius, J., Pratto, F., van Laar, C., \& Levin, S. (2004). Social dominance theory: Its agenda and method. Political Psychology, 25(6), 845-880.

Sison, A.J.G. (1999). Business and culture in the Philippines: A story of gradual progress. In P.H. Werhane \& A.E. Singer (Eds.), Business ethics in theory and practice: Contributions from Asia and New Zealand (pp. 145-166). Dortrecht: Kluwer Academic Publishers.

Spicer, J. (2005). Making sense of multivariate data analysis. Thousand Oaks, CA: Sage Publications.

Spreitzer, G.M. (1995). Psychological empowerment in the workplace: Dimensions, measurement and validation. Academy of Management Journal, 38(5), 14421465.

Spreitzer, G.M. (2008). Taking stock: A review of more than twenty years of research on empowerment at work. In C. Cooper \& J. Barling (Eds.), The handbook of organizational behavior (pp. 54-72). London: Sage Publications.

Spreitzer, G.M., Kizilos, M.A., \& Nason, S.W. (1997). A dimensional analysis of the relationship between psychological empowerment, effectiveness, satisfaction and strain. Journal of Management, 23(5), 679704 .

Tajfel, H., \& Turner, J.C. (2004). An integrative theory of intergroup conflict. In J. Hatch \& M. Schultz (Eds.), Organizational identity: A reader (pp. 56-65). Oxford: Oxford University Press.
Thibaut, J., \& Walker, L. (1978). A Theory of Procedure. Californian Law Review, 66(3), 541-566.

Thomas, K.W., \& Velthouse, B. A. (1990). Cognitive elements of empowerment: An 'interpretive' model of intrinsic task motivation. The Academy of Management Review, 15(4), 666681.

Toh, S.M., \& Denisi, A.S. (2007). Host country nationals as socializing agents: A social identity approach. Journal of Organizational Behavior, 28, 281-301.

Turner, J.C., \& Reynolds, K.J. (2003). Why social dominance theory has been falsified. British Journal of Social Psychology, 42, 199-206.

United Nations. (2000). Millenium development goals. Retrieved 21 December, 2010, from http://www.un.org/ millenniumgoals/poverty.shtml

United Nations. (2010). The millenium development goals report: 2010. New York: United Nations.

Varma, A., Toh, S.M., \& Budhwar, P. (2006). A new perspective on the female expatriate experience: The role of host country national categorization. Journal of World Business, 41, 112120.

Wenar, L. (2006). Accountability in international development aid. Ethics \& International Affairs, 20(1), 1-23.

Zani, B., \& Pietrantoni, L. (2001). Gender differences in burnout, empowerment and somatic symptoms among health professionals: Moderators and mediators. Equal Opportunities International, 20(1), 39-48. 